\title{
Status of Community Resilience in Disaster Prone Districts of Baluchistan, Pakistan
}

\author{
Nasrullah', Syed Ainuddin'2, Khair Muhammad Kakar ${ }^{3}$ \\ ${ }^{1}$ Pakistan Study Center, University of Balochistan, Quetta, Pakistan \\ ${ }^{2}$ University of Balochistan, Quetta, Pakistan \\ ${ }^{3}$ Department of Agriculture, Government of Balochistan, Quetta, Pakistan \\ Email: nasrullah00@yahoo.com,syed.ainuddin77@gmail.com,agrarian786@yahoo.com
}

Received 28 September 2015; accepted 24 November 2015; published 27 November 2015

Copyright (C) 2015 by authors and Scientific Research Publishing Inc.

This work is licensed under the Creative Commons Attribution International License (CC BY). http://creativecommons.org/licenses/by/4.0/

(c) ()

\section{Abstract}

Resilience to natural hazards and disasters is inevitable when linked with community. Social resilience is the key to achieve risk reduction measures at the local levels. The objective of the paper is to assess the community resilience of the three disaster prone districts in Balochistan. A sample of 399 households was selected using stratified sampling with proportional allocation method. Four components of community resilience were assessed. The results reveal that in all components of resilience district Ziarat was more resilient compared with other two districts followed by district Jaffarabad and Nushki. The article recommends that certain initiatives may be take in the other districts also to enhance the community resilience to different disasters particularly by conducting awareness complains, diversification of income sources, and physical structure to various natural hazards.

\section{Keywords}

Status, Community, Resilience, Disaster, Pakistan

\section{Introduction}

Today, the world is facing disasters on an unprecedented scale: more than 255 million people were affected by natural disasters globally each year, on average, between 1994 and 2003, with a range of 68 million to 618 million. During the same period, these disasters claimed an average of 58,000 lives annually, with a range of 10,000 to 123,000 . In the year 20031 in 25 people worldwide was affected by natural disasters. During the last decade disasters caused damage of an estimated US\$ 67 billion per year on average, with a maximum of US\$ 230 billion and a minimum of US\$ 28 billion. The economic cost associated with natural disasters has increased 14- 
fold since the 1950s (D.G. Sapir, et al., 2004 [1]). The number of people affected by natural disasters around the world is rising. Over the past two years, 700 natural disasters were registered worldwide affecting more than 450 million people. Damages have risen from an estimated US\$20 billion on average per year in the 1990s to about US $\$ 100$ billion per year during 2000-2010. This upward trend is expected to continue as a result of the rising concentration of people living in areas more exposed to natural disasters, and climate change. The international community is focused on increasing community resilience to decreased the effect of natural disasters, The Hyogo Framework of Action 2005-2015 added a new impetus to what affected communities can do for themselves and how to strengthen their capacities, rather than concentrating on their vulnerability or their need in emergency. Resilience is becoming an increasing part of disaster studies and related disciplines. This has become particularly prevalent after the adoption of the Hyogo Framework for Action in 2005, which sought to enhance resilience to disasters. As a result, several competing notions and definitions of resilience have flourished. The argument is that it is about learning from the progressive and spatial scales of the adaptive capacity, transformative processes, and maintenance of structures and recovery of systems, institutions, communities or individuals following a disaster.

In Pakistan, flood of July 2010, resulted 1539 deaths, 2055 injured, 6 million displaced. 1226678 houses destroyed/damaged, 7820 schools \& 200 hospitals destroyed. The same flood affected 17.2 Million as \% age of total national population (10.35\%). In Pakistan natural disasters in 1991 stretching from Chitral to Gilgit was shaken up by an Earthquake of magnitude 6.8 on Richter scale \& affected 100 villages. 2900 houses were destroyed, 14786 houses were damaged. In Earthquake of $8^{\text {th }}$ October, 2005, 73,000 people killed, 3 million affected, 60,000 houses, 6000 schools and 500 health facilities were destroyed. In Balochistan, Ziarat, the earthquake of 2008 caused 155 deaths, 375 injured, 14 villages destroyed, 35000 people were badly affected \& 12000 people were displaced along with 38 health facilities were damaged. While in Balochistan, The Drought of 1997-2002 has been termed as one of the worst natural disaster in the history of the Province. This resulted \& caused slowing the economic growth rate down to $2.6 \%$ during the period concerned. While this drought caused a loss of PKR 25 billion to the national exchequer in the year 2000-2002 (Balochistan Disaster Management Authority, 2008 [2]). Balochistan, province of Pakistan is by far the largest in size and the smallest in population. The Province covers 34.7 million hectares, almost $44 \%$ of the country's land area, with a population of about 8 million people (12 persons per sq. km.). The province is located in South-Western (220N to 320N, 660E to 700E) Pakistan. About $80 \%$ of the area can be classified as inter-mountainous. The remaining $20 \%$ consists of flood plains and coastal plains. Balochistan is affected with plethora of natural and human induced hazards that threaten to affect the lives and livelihoods of its citizens-natural hazards like Floods, Land Sliding, Earthquakes, and Drought are common hazards in the province (Balochistan Disaster Plan, 2006 [3]).

The broad objective of the study was to determine the resilience status of society to natural disaster and change Impacts in nine most disaster affected union councils of three disaster prone districts of Baluchistan.

\section{Conceptual Framework for Community Resilience}

Evaluating community resilience is a complicated process because of the vibrant relations of people, community, societies, and the environment. Various authors developed various frameworks to measure the community resilience (Cutter et al. 2010, Ainuddin S., 2012, Buckle, 2006; Foster, 2006; and Tierney, 2006, Adger, 2000, and Joseph S., 2010 [4]) these frameworks conceptualized the disaster resilience focusing the vulnerability reduction indicators including social economical, human and physical aspects of community resilience except Joseph S. Mayunga conceptualized the capital based approach (Figure 1).

\section{Materials and Methods}

The research study was conducted in nine most affected union councils of three vulnerable districts of Balochistan including Ziarat, Nushki \& Jaffarabad. The study was as part of Ph.D. thesis of Pakistan Study Centre 2015, the methodology used for research was: The secondary data were collected from a large number of books, Reports, published articles, reputable Journals and web sites, The Data were reviewed to understand macro dimension of the issues and ripple effects of those historical events that have shaped situation as of today. The Primary data was collected through a Questionnaire from 398 Households of targeted districts. Opinion of households from three districts from different segments of the district was collected through a questionnaire, which was design from findings of focus group discussions held earlier. Key Informative interviews were conducted with the 


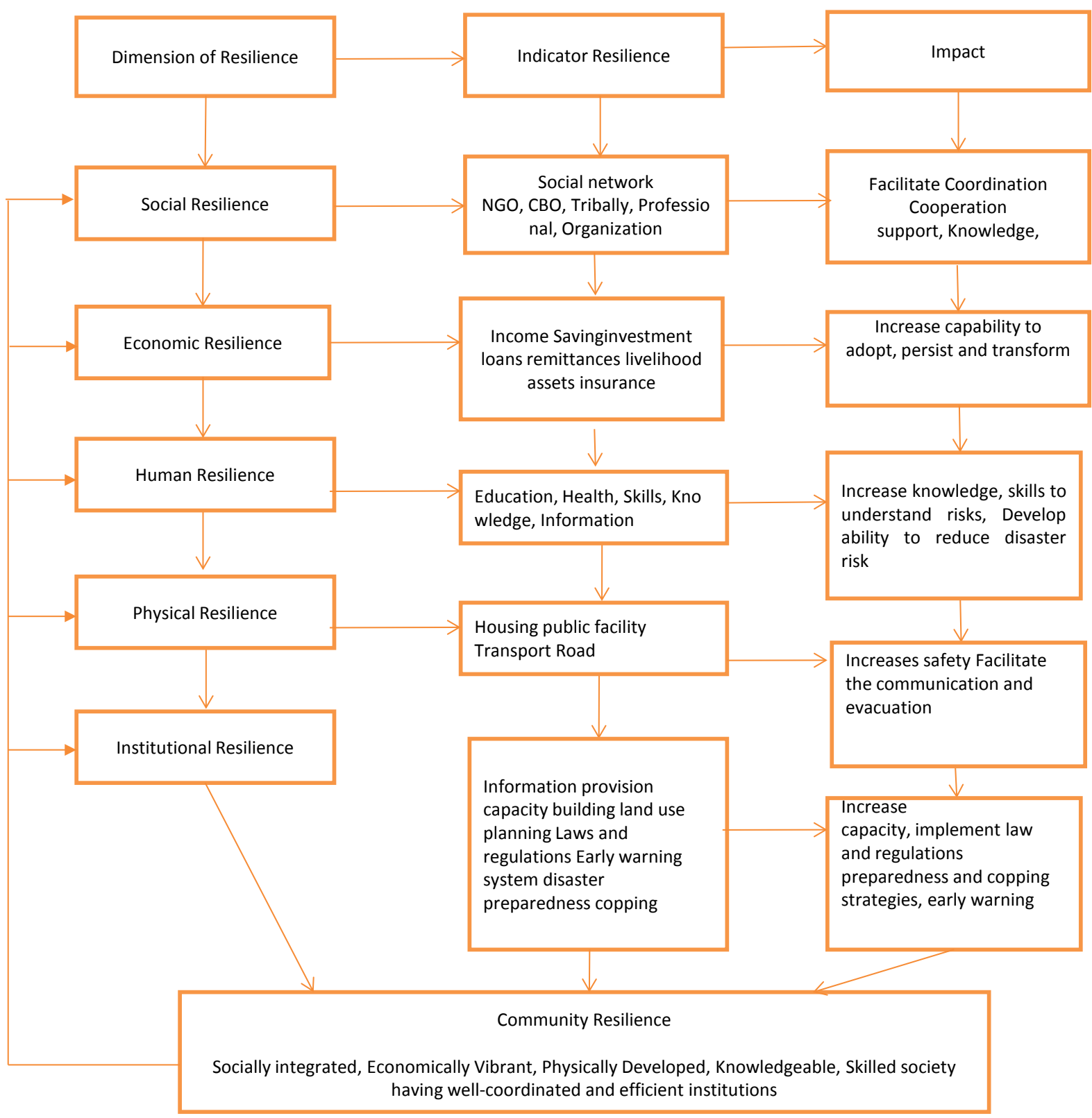

Figure 1. Conceptual framework for community resilience. Adopted from Cutter 2010, Ainuddin. S. 2012, Joseph S. Mayunga, a capital-based approach.

personals and experts of line departments of district and their views were obtained on the research study.

Study Sample: Study respondents were selected from low, middle and high-income households with selection probability proportional to population size. Participants within each stratum were selected by a random method.

Sample size: Nine most district effected union councils of three disaster proven districts were selected for the household survey, including Union council Kishingi, Anam Bostan and Daak of district Nushki which were seriously affected by drought, Union Council Kuch, Sapro and Kawas from district Ziarat were most effected by 2008 earthquake, Union Council Cattle farm, Rojhan Jamali and Band Manik from district Jaffarabad were seriously effected by 2011 and 2012 flood. The districts are divided into three strata. The sample size was derived on the basis of the total population of the nine union councils of three districts that is approximately 159,457 as per census and statistical bureau of Pakistan. Sample size was calculated through Yamane formula as follows (Yamane 1967). 


$$
\mathrm{I}: \text { Sample size }=\frac{\mathrm{N}}{1+\mathrm{N}(\mathrm{e}) 2}=\frac{159,457}{1+159,457(0.05) 2}=398
$$

Hence a total of 399 samples were selected using stratified sampling with proportional allocation method according the households number in each zone with confidence level of $95 \%$ and confidence interval of $5 \%$. First the districts are divided into three stratums and then random or systematic sampling was applied within each stratum.

With proportionate stratification, the sample size of each stratum is proportionate to the population size of the stratum. Strata sample sizes are determined by the following equation:

$$
\mathrm{II}: \mathrm{nh}=(\mathrm{Nh} / \mathrm{N}) \times \mathrm{n}
$$

where nh is the sample size for stratum $h$, Nh is the population size for stratum $h, \mathrm{~N}$ is total population size, and $\mathrm{n}$ is total sample size.

Calculation of sample size of each stratum:

For District Jaffarabad: $\mathrm{nh}=(\mathrm{Nh} / \mathrm{N}) \times \mathrm{n}=(93,934 / 159,457) \times 398=234$

For District Nushki: $\mathrm{nh}=(\mathrm{Nh} / \mathrm{N}) \times \mathrm{n}=(45,548 / 159,457) \times 398=114$

For District Ziarat: $\mathrm{nh}=(\mathrm{Nh} / \mathrm{N}) \times \mathrm{n}=(19,975 / 159,457) \times 398=50$

Sampling strategy: Quantitative data were collected through household visits in three districts and select households using random selection methods. In each district, village as primary sampling unit were considered. Sampling element for the survey was household male and female of affected villages and has been residing in the area for at least one year. A random number of households were selected (PSU), through simple random sampling from the list of area compiled by the villages. Adjacent smaller villages were collapsed to consider them as one cluster to have at least 50 households in each cluster.

\section{Results and Discussions}

The community resilience was assessed using the percentage scale developed by S. Ainuddin-2013. The scale is ranging from 0 to 1 where 0 indicated the lower resilience and 1 highest resilience, however in some indicators the highest value showed the lowest resilience. The results were pertaining on four sections likewise.

1). Social Resilience

Data highlighted in Table 1 of component indicators in three disaster prone districts of Balochistan revealed that $0.3 \%$ people with 6 optimum level were having high school \& above education in district Nushki. 2.16\% people with 1.5 optimum level were having less than 45 years age. $0.82 \%$ people with 2 optimum level were having age of less than 15 years. $0.04 \%$ people with 2 optimum level were without any health insurance facility. $1.16 \%$ people having 7 optimum level were without any physical \& mental disability and $1.12 \%$ community trust with 5 optimum level were present during disasters in district Nushki. It is evident fromthe figures presented in Table 1 that $0.69 \%$ people with 6 optimum level were having high school and above education in district Ziarat. 1.64\% people with 1.5 optimum level were having less than 45 years age. $0.56 \%$ people with 2 optimum level were having age of less than 15 years. $0.01 \%$ people having 2 optimum level were without any kind of health insurance. $1.17 \%$ people having 7 optimum level were without any physical \& mental disability \& $1.2 \%$

\begin{tabular}{|c|c|c|c|c|c|}
\hline \multirow[t]{2}{*}{ S\# } & \multirow[t]{2}{*}{ Component indicators } & \multirow[b]{2}{*}{ (Nushki) } & \multirow[b]{2}{*}{ (Ziarat) } & \multirow[b]{2}{*}{ (Jaffarabad) } & \multirow[b]{2}{*}{ Optimum level } \\
\hline & & & & & \\
\hline 1 & Percent of people with high school and above education & 0.3 & 0.69 & 0.23 & 6 \\
\hline 2 & Percent of people $>45$ years of age & 2.16 & 1.64 & 1.69 & 1.5 \\
\hline 3 & Percent of people $<15$ years of age & 0.82 & 0.56 & 0.48 & 2 \\
\hline 4 & Percent of people with health insurance & 0.04 & 0.01 & 0.32 & 2 \\
\hline 5 & Percent of people without any physical and mental disability & 1.16 & 1.17 & 1.19 & 7 \\
\hline 6 & Community trust during disaster & 1.12 & 1.2 & 0.69 & 5 \\
\hline
\end{tabular}
community trust having 5 optimum level were present during disasters in district Ziarat. Similarly, $0.23 \%$ people 
having 6 optimum level were having high school and above education in district Jaffarabad. 1.69\% people with 1.5 optimum level were having less than 45 years age. $0.48 \%$ people having 2 optimum level were having age of less than 15 years. $0.32 \%$ people having 2 optimum level were without any kind of health insurance. $1.19 \%$ people with 7 optimum level were without any physical and mental disability and $0.69 \%$ community trust having 5 optimum level were present during disasters in district Jaffarabad. In all three disasters prone districts of the province namely Nushki, Ziarat \& Jaffarabad, the higher and maximum education level $0.69 \%$ having 6 optimum level was availed by the communities living in district Ziarat of Balochistan, followed by $0.3 \%$ in Nushki $\&$ the lowest education level $0.23 \%$ was availed by the communities living in Jaffarabad district of Balochistan. These results are in conformity with Norris et al. 2008, Morrow 2008 \& Cutter et al. 2010 [5]. That argue that higher education level raises the awareness and preparedness activities of the communities. The maximum age group 2.16\% people with 1.5\% optimum level were living in district Nushki of Balochistan, followed by 1.69\% in Jaffarabad \& the minimum age group people $1.64 \%$ were in District Ziarat. The normal age group people greater than 15 years of age with 2 optimum level were $0.82 \%$ were living in District Nushki of Balochistan, followed by $0.56 \%$ in Ziarat and the minimum age group $0.48 \%$ were living in Jaffarabad. These results are in line with Morrow, 2008, Cutter et al. 2010, Cutter et al. 2010 Tobin et al. 1999 \& Cutter et al. 2003 [6]. This mean that Nushki is vulnerable or less resilient in terms of age group of the communities. The best and ideal availability of health insurance facility in all three disasters prone districts of the province $0.32 \%$ having 2 optimum level were prevailing with the communities of district Jaffarabad in Balochistan, followed by $0.04 \%$ in Nushki \& the minimum health insurance facility 0.01 was available with the communities of Ziarat. These results are in agreement with Heinz Center 2002 \& Cutter et al. 2010 [7]. The ideal situation in relation to the high \& maximum non-availability of physical \& mental disability $1.19 \%$ with 7 optimum level was prevailing in District Jaffarabad of Balochistan, followed by $1.17 \%$ in district Ziarat \& the minimum $1.16 \%$ was prevailing in district Nushki. More or less similar situation is discussed in the three districts in term of physical accessibility. However, the maximum \& higher level of community trust during disasters $1.2 \%$ with 5 optimum level were existed in the communities of District Ziarat, followed by $1.12 \%$ in Nushki \& the minimum $0.69 \%$ community trust level during disasters were prevailing in District Jaffarabad. These results are in line with Heinz Center 2002 \& Cutter et al. 2010 [7]. The situation of community trust that has to be very higher in rural communities is not assured in the study area except Ziarat. This indicated that communities themselves do not have trust and collective wisdom to work during any disaster (Figure 2).

The plausible reason for prevailing maximum education level in district Ziarat could be more exposure about the polish urban life of the Visitors \& tourists visiting regularly the areas of Ziarat along with more interaction with them. As the respective communities could be more impressed with the hi-fi \& luxurious life of tourist \& this inspiration could be the reason of getting more education by the communities of district Ziarat. The second possible reason for getting maximum education by the communities of Ziarat could be the nearest location of Ziarat with provincial headquarters Quetta.

2). Economic Resilience (Component Indicator)

Data mentioned in Table 2 in relation percentage of several component indicators in three disasters proven districts of Balochistan. Interpretation of the statistical data showed that 1.64\% people with 6 optimum level were having ownership of their own houses in district Nushki. 1.98\% people with 5 optimum level were having employment in several departments and organizations. 1.02\% people with 5 optimum level were having multiple source of income. $0.75 \%$ people with 5 optimum level were above poverty line in Nushki district. While, $1.34 \%$ component resilience factor index was prevailing in district Nushki. It is confirmed form the results presented in table that $1.7 \%$ people with 6 optimum level were having their own houses with ownership in district Ziarat. $2 \%$ people with 5 optimum level were having their own jobs \& employed. $1.46 \%$ people with 5 optimum level were having multiple source of income in district Ziarat. $0.64 \%$ people having 9 optimum level were above poverty line. The average component resilience factor index in district Ziarat was $1.45 \%$ Similarly, It is crystal clear from the results that $1.63 \%$ people with 6 optimumlevel were having their own houses with ownership in district Jaffarabad. 1.92\% people with 5 optimum level were having their own jobs \& employed. 0.57\% people with 5 optimum level were having multiple source of income in District Jaffarabad. 0.86\% people having 9 optimum level were above poverty line. The average component resilience factor index 1.24\% was in district Jaffarabad.

In all three disaster prone districts of the province namely Nushki, Ziarat \& Jaffarabad, the higher \& maximum house ownership was $1.7 \%$ having 6 optimum level was availed by the communities living in district Ziarat of Balochistan, followed by $1.64 \%$ in Nushki \& the lowest $1.63 \%$ ownership of houses was in Jaffarabad 


\section{Social Resilience}

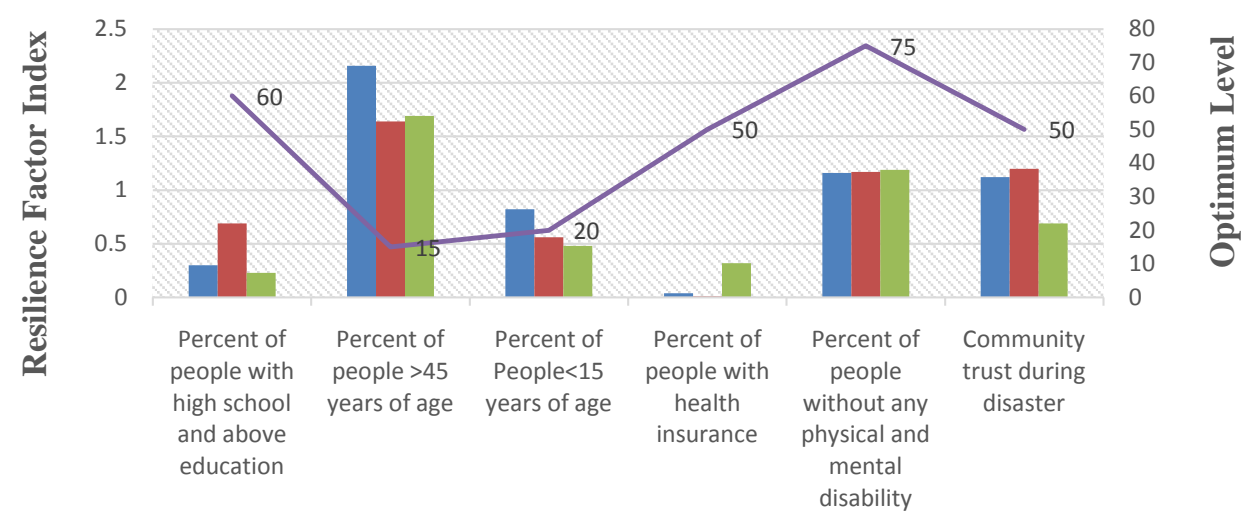

(Nushki) (Ziarat) (Jaffarabad) Optimum Level

Figure 2. Social resilience. Source: primary field survey 2015.

Table 2. Economic resilience.

\begin{tabular}{|c|c|c|c|c|c|}
\hline \multicolumn{6}{|c|}{ Component indicators } \\
\hline & & $\begin{array}{l}\text { Resilience factor } \\
\text { index (Nushki) }\end{array}$ & $\begin{array}{l}\text { Resilience factor } \\
\text { index (Ziarat) }\end{array}$ & $\begin{array}{l}\text { Resilience factor index } \\
\text { (Jaffarabad) }\end{array}$ & $\begin{array}{l}\text { Optimum level of } \\
\text { resilience }\end{array}$ \\
\hline 1 & Percent of house ownership & 1.64 & 1.7 & 1.63 & 6 \\
\hline 2 & Percent of people employed & 1.98 & 2 & 1.92 & 5 \\
\hline 3 & $\begin{array}{l}\text { Percent of households with } \\
\text { multiple source of income }\end{array}$ & 1.02 & 1.46 & 0.57 & 5 \\
\hline \multirow[t]{2}{*}{4} & $\begin{array}{l}\text { Percent of population above } \\
\text { poverty line }\end{array}$ & 0.75 & 0.64 & 0.86 & 9 \\
\hline & $\begin{array}{l}\text { Component resilience factor } \\
\text { index (average) }\end{array}$ & 1.34 & 1.45 & 1.24 & \\
\hline
\end{tabular}

district of Balochistan. These results are in conformity with Tiemey 2001 [6]. The maximum number of people employed $2 \%$ with $5 \%$ optimum level of resilience were living in district Ziarat. Followed by $1.98 \%$ in Nushki $\&$ the minimum number of people of employed $1.92 \%$ with 5 optimum level of resilience were in District Jaffarabad. The maximum number of household with multiple source of income $1.46 \%$ with 5 optimum level of resilience were living in District Ziarat of Balochistan, followed by 1.02\% in Nushki \& the minimum households with multiple source of Income $0.57 \%$ having 5 multiple level of resilience were living in Jaffarabad. The maximum percent of population above poverty line $0.86 \%$ hiving 9 optimum level of resilience were present in district Jaffarabad of Balochistan, followed by $0.75 \%$ were observed in District Nushki. While the minimum percentage of population above poverty line $0.64 \%$ were observed in Ziarat. These results are in line with Ager, 2000 \& cutter et al. 2000 [8]. The maximum average component resilience factor in district Ziarat was 1.45\%, followed by $1.34 \%$ in District Nushki \& the Minimum Component resilience factor index was noted in District Jaffarabad of Balochistan. The possible reason for prevailing maximum ownership of houses in district Ziarat could be the construction of houses within the orchards \& as the population of the said district is comparatively very less. As a result more the more percentage of the community were employed. Less population above poverty line could be the maximum education \& maximum number of community members in jobs in District Ziarat. The Figure 3 results that there is great gap between the actual and expected value of poverty that confines that districts having high poverty level remain vulnerable.

3). Institutional Resilience (Component Indicator)

Data reflected in Table 3 in relation percentage of several component indicators in threope disaster prone districts of Balochistan. It is evident from the data that $0.53 \%$ population having 5 optimum level of resilience 


\section{Economic Resilience}

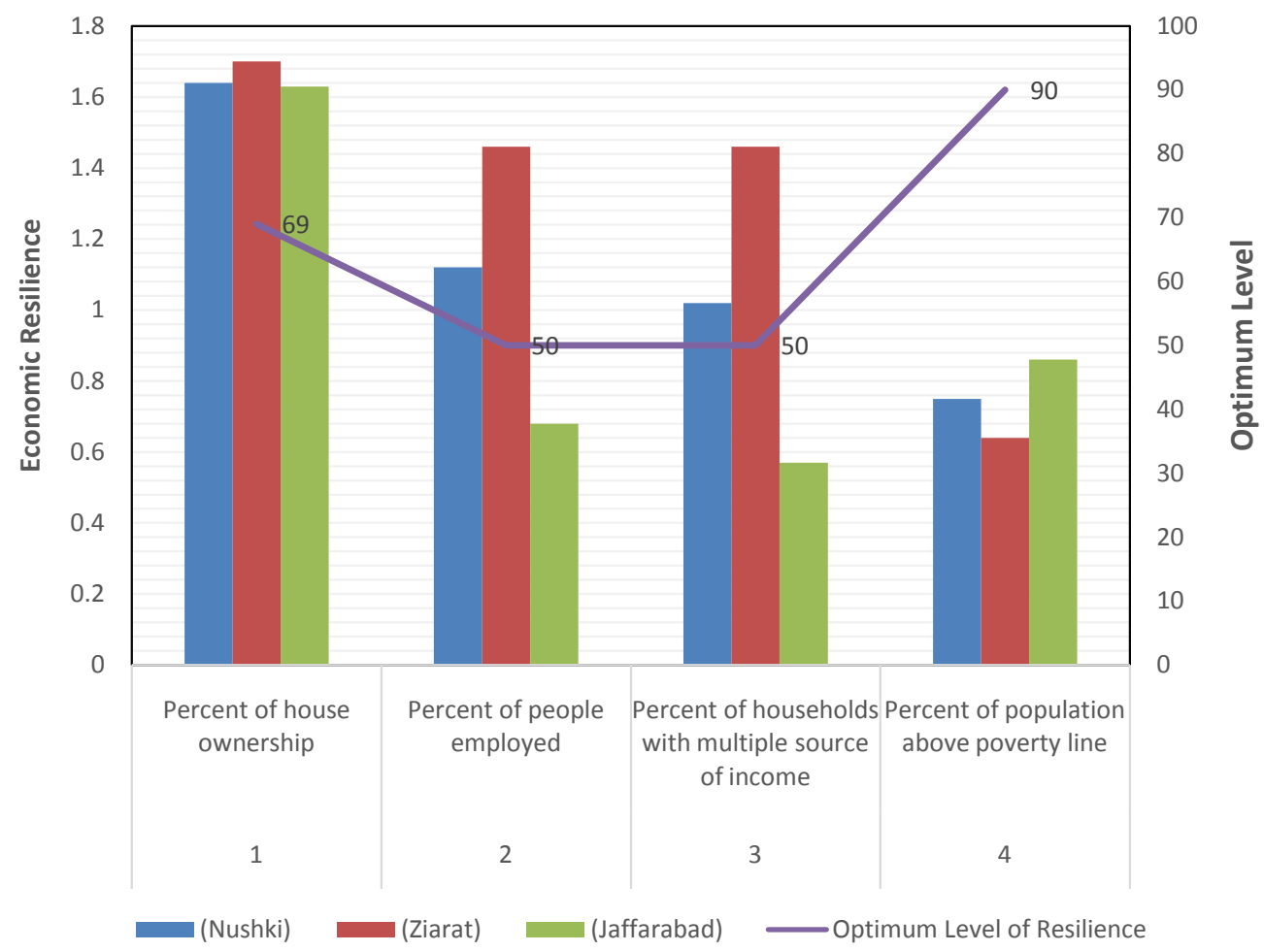

Figure 3. Economic resilience. Source: primary field survey 2015.

Table 3. Institutional resilience.

\begin{tabular}{|c|c|c|c|c|c|}
\hline \multicolumn{6}{|c|}{ Component Indicators } \\
\hline & & $\begin{array}{l}\text { Resilience factor } \\
\text { index (Nushki) }\end{array}$ & $\begin{array}{l}\text { Resilience factor } \\
\text { index (Ziarat) }\end{array}$ & $\begin{array}{l}\text { Resilience factor } \\
\text { index (Jaffarabad) }\end{array}$ & $\begin{array}{l}\text { Optimum level of } \\
\text { resilience }\end{array}$ \\
\hline 1 & $\begin{array}{l}\text { Percentage of population covered by } \\
\text { hazard mitigation plan }\end{array}$ & 0.17 & 0.53 & 0.35 & 5 \\
\hline 2 & $\begin{array}{l}\text { Percent of municipal expenditure for } \\
\text { fire and emergency management }\end{array}$ & 0.2 & 0.3 & 0.46 & 1.5 \\
\hline \multirow[t]{2}{*}{3} & $\begin{array}{l}\text { Percent of people with disasters } \\
\text { Preparedness education }\end{array}$ & 0.09 & 0.16 & 0.2 & 5 \\
\hline & $\begin{array}{l}\text { Component resilience factor index } \\
\text { (average) }\end{array}$ & 0.15 & 0.33 & 0.34 & \\
\hline
\end{tabular}

were covered by hazard migration plan in district Ziarat, followed by $0.35 \%$ having same 5 optimum level of resilience and the minimum $0.17 \%$ population with 5 optimum level of resilience were covered by hazard migration plan in district Nushki. The maximum percentage $0.46 \%$ having $1.5 \%$ optimum level of resilience of municipal expenditure for fire and emergency management were noted in district Jaffarabad, followed by $0.3 \%$ having same 1.5 optimum level of resilience were recorded in district Ziarat $0.2 \%$ with same 1.5 optimum level of resilience were noted in district Nushki. Maximum $0.2 \%$ having 5 optimum level of resilience were observed with disasters preparedness education in District Jaffarabad of Balochistan, followed by $0.16 \%$ people with disasters preparedness education having same 5 optimum level of resilience were recorded in district Ziarat and the minimum $0.09 \%$ having same 5 optimum level of resilience were recorded in District Nushki. Similarly, the average $\mathbf{0 . 1 5 \%}$ component resilience factor index was noted in District Nushki. $0.33 \%$ average component resilience index were noted in district Ziarat and 0.34\% average component resilience index were recorded in district Jaffarabad of Balochistan.

In all three disasters prone districts of the province namely Nushki, Ziarat \& Jaffarabad, the higher \& maxi- 
mum percentage of population $0.53 \%$ were covered by disasters management plan in District Ziarat. These results in agreement with Godschalk, 2007. The maximum municipal expenditure for fire \& emergency $0.56 \%$ were observed in District Jaffarabad. These lines are in conformity with Sylves, 2007. The maximum and highest $0.2 \%$ people with disasters preparedness education were noticed in district Jaffarabad of Balochistan. These results are in conformity with Paton et al., 2001. The solid reason for prevailing maximum number of people or community members covered under disasters management plan could be the less population \& organized population of the district concerned. Similarly as more municipal expenditure were observed in District Jaffarabad, the possible reason for such expansion could be the bigger size of the district head quarter as several municipal services were prevailing in Jaffarabad (Figure 4).

4). Physical Resilience (Component Indicator)

Data highlighted in Table 4 in relation percentage of several component indicators in three disaster prone districts of Balochistan. The data showed that maximum $0.3 \%$ vacant houses with 6 optimum level of resilience were prevailing in district Jaffarabad, followed by $0.26 \%$ vacant houses with same 6 optimum level of resilience in District Nushki \& very less rather minimum number of vacant houses $0.14 \%$ having same 6 optimum level of resilience were prevailing in district Ziarat. It is evident from the tabulated data as presented in the Table 4

\section{Institutional Resilience}

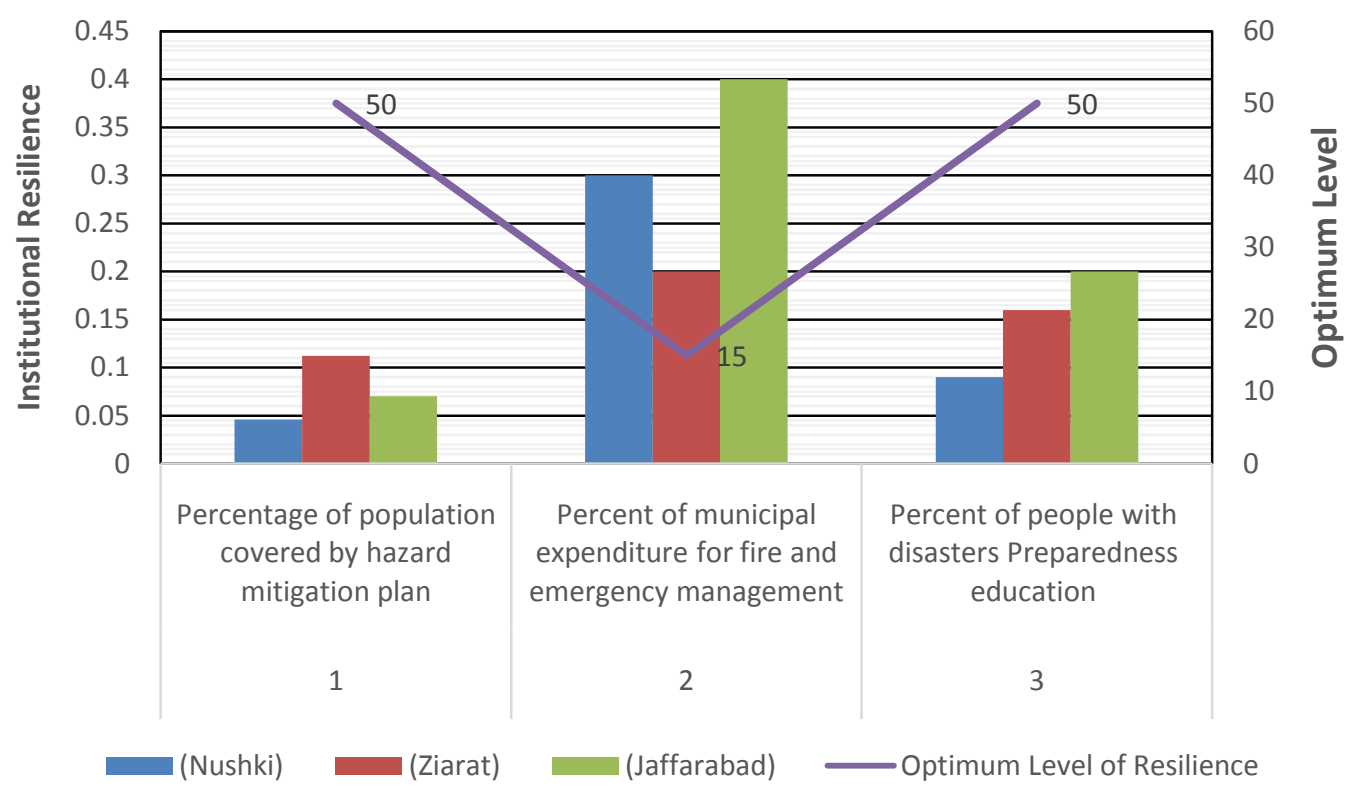

Figure 4. Institutional resilience. Source: primary field survey 2015.

Table 4. Physical resilience.

\begin{tabular}{|c|c|c|c|c|c|}
\hline S\# & Component Indicators & & & & \\
\hline & & $\begin{array}{l}\text { Resilience factor } \\
\text { index (Nushki) }\end{array}$ & $\begin{array}{l}\text { Resilience factor } \\
\text { index (Ziarat) }\end{array}$ & $\begin{array}{l}\text { Resilience factor index } \\
\text { (Jaffarabad) }\end{array}$ & $\begin{array}{l}\text { Optimum level of } \\
\text { resilience }\end{array}$ \\
\hline 1 & Percent of vacant rental houses & 0.26 & 0.14 & 0.3 & 6 \\
\hline 2 & $\begin{array}{l}\text { Percent of houses with wood as } \\
\text { construction material }\end{array}$ & 0.24 & 0.44 & 0.35 & 6 \\
\hline 3 & $\begin{array}{l}\text { Percent of housing units following } \\
\text { the buildings rules of } 1935\end{array}$ & 0 & 0.28 & 0.01 & 6 \\
\hline \multirow[t]{2}{*}{4} & $\begin{array}{l}\text { Percent of housing units located in } \\
\text { core of the city }\end{array}$ & 0.4 & 0.4 & 0.4 & 4 \\
\hline & $\begin{array}{l}\text { Component resilience factor index } \\
\text { (average) }\end{array}$ & 0.26 & 0.3 & 0.27 & \\
\hline
\end{tabular}


that maximum number of houses $0.44 \%$ with 6 optimum level of resilience were made from wood in district Ziarat, followed by $0.35 \%$ houses were made from wood in district Jaffarabad and $0.24 \%$ houses with same 6 optimum level of resilience were made from wood in district Nushki. Maximum number of houses $0.28 \%$ with 6 optimum level of resilience had followed the building rules of 1935 in district Ziarat and the minimum number of houses $0.01 \%$ with 6 optimum level of resilience were noticed in district Jaffarabad build and constructed under the building rules of 1935 .Similarly, almost with equal ratio $0.4 \%$ and with equal optimum level of resilience 4 , the percentage of housing units were located in the core of the cities of respective disasters vulnerable district like Nushki, Ziarat and Jaffarabad of Balochistan. The maximum average component resilience factor in district Ziarat was $0.3 \%$, followed by $0.27 \%$ in District Jaffarabad \& the Minimum Component resilience factor index $0.26 \%$ was noted in District Nushki of Balochistan.

In all three disasters prone districts of the province namely Nushki, Ziarat \& Jaffarabad, the higher \& maximum vacant houses $0.3 \%$ were located in District Jaffarabad having 6 optimum level (Figure 5). The maximum number of houses $0.44 \%$ were made from wood with $6 \%$ optimum level of resilience in district Ziarat. The maximum number of houses observed were made under the building rules of 1935 with 6 optimum level of resilience in District Ziarat of Balochistan. While almost all number of Houses were observed located in the core of cities in all three districts of the province. These results are in line with Taubenbock et al., 2008 [9]. The reasonable reason for several vacant houses availability in district Jaffarabad would be during the harsh summer season almost half of the local population is supposed to migrate from their villages towards comparatively cold areas from May to September every year. Similarly as educational ratio in Ziarat is satisfactory. So as a result, the concerned community is well aware about the rules and regulations of construction in the entire district. The possible reason for location of houses in the core of cities would be due to lack of cities in the remaining parts of the entire district, so the houses are located in the down town in all city headquarters of the respective districts.

\section{Conclusion}

The purpose of the assessment was to cheek the community resilience status of three disaster prone districts in Baluchistan. The results indicate that the three vulnerable districts show very poor resilience level to withstand to natural disasters. However among the three districts the results of district Ziarat is encouraging followed by Jaffar Abad and Nushki districts. The article has highlighted for the first time that assessment of various com-

\section{Physical resilience}

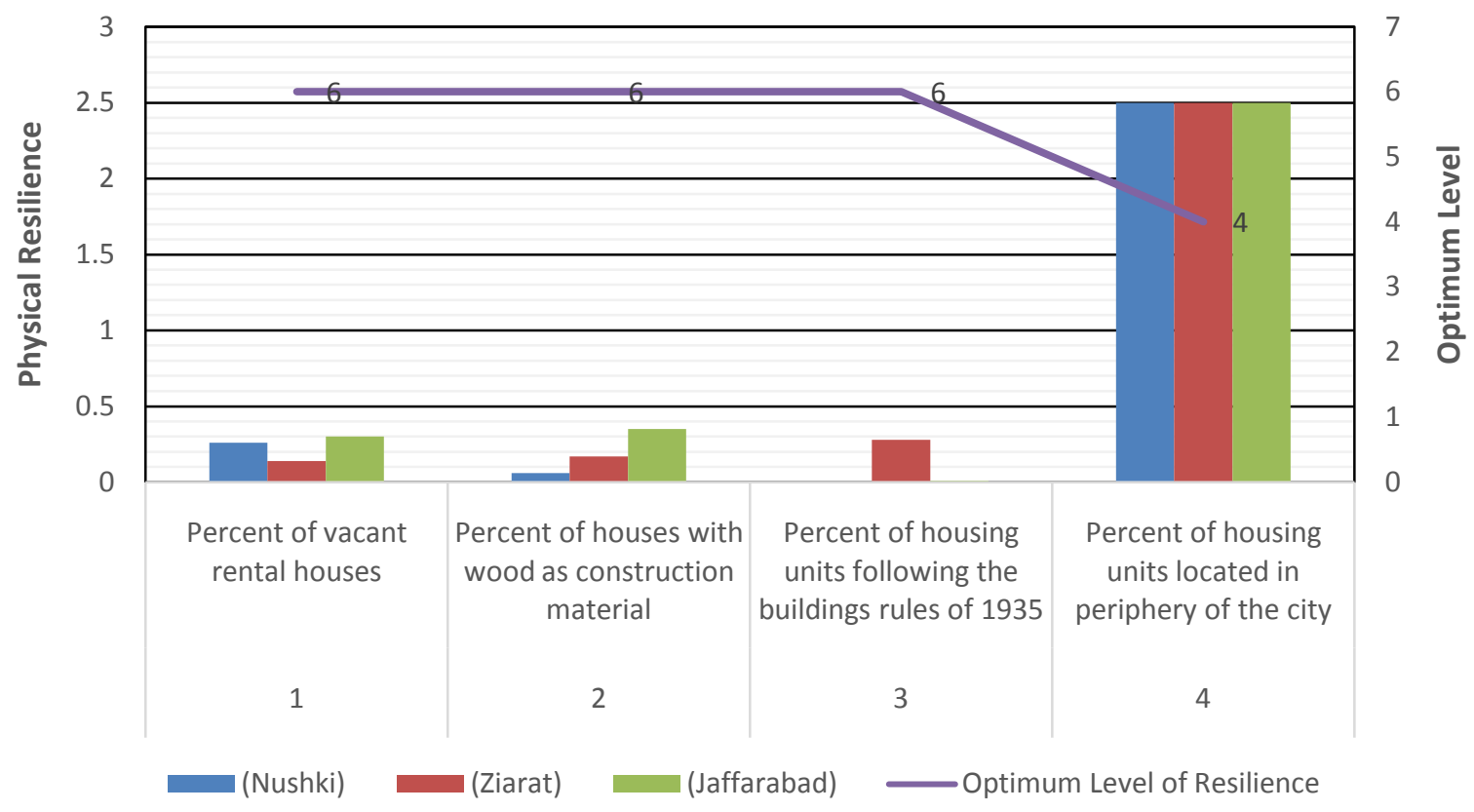

Figure 5. Physical resilience. Source: Primary field survey 2015. 
ponents has to be carried out before going for mitigation measures. In addition the article also recommends the awareness programs, diversified sources of income and structural and institutional measures to deal disasters at the local levels in Pakistan.

\section{References}

[1] Guha-Sapir, D., Hargitt, D. and Hoyois, P. (2004) Thirty Years of Disasters 1974-2003: The Numbers. Centre for Research on the Epidemiology of Disasters.

[2] Balochistan Disaster Management Authority 2008.

[3] Balochistan Disaster Management Plan 2006.

[4] Cutter, L.S., Burton, G.C. and Emrich, T.C. (2010) Disaster Resilience Indicators for Benchmarking Baseline Conditions. Journal of Homeland Security and Emergency Management, 7, 1-22. http://dx.doi.org/10.2202/1547-7355.1732

[5] Tobin, G. (1999) Sustainability and Community Resilience: The Holy Grail of Hazard Planning? Environmental Hazards, 1, 13-25. http://dx.doi.org/10.1016/s1464-2867(99)00002-9

[6] Tierney, K.J., Lindell, M.K. and Perry, R.W. (2001) Facing the Unexpected: Disaster Preparedness and Response in the United States, Natural Hazards and Disasters. Joseph Henry Press, Washington.

[7] Paton, D. and Fohnston, D. (2001) Disasters and Communities: Vulnerability, Resilience and Preparedness. Disaster Prevention and Management, 10, 270-277. http://dx.doi.org/10.1108/EUM0000000005930

[8] Adger, W.N. (2000) Social and Ecological Resilience: Are They Related? Progress in Human Geography, 24, $347-364$. http://dx.doi.org/10.1191/030913200701540465

[9] Taubenbock, H., Post, J., Roth, A., Zosseder, K., Strunz, G. and Dech, S. (2008) A Conceptual Vulnerability and Risk Framework as Outline to Identify Capabilities of Remote Sensing. Natural Hazards and Earth System Sciences, 8, 409420. http://dx.doi.org/10.5194/nhess-8-409-2008 